\title{
Potato response to silicone compounds (micro and nanoparticles) and potassium as affected by salinity stress
}

\author{
Mohammad Kafi, ${ }^{1,2}$ Jafar Nabati, ${ }^{2}$ Bijan Saadatian, ${ }^{3}$ Armin Oskoueian, ${ }^{3}$ Javad Shabahang ${ }^{4}$ \\ ${ }^{1}$ Faculty of Agriculture, Ferdowsi University of Mashhad; ${ }^{2}$ Research Centre for Plant Sciences, Ferdowsi \\ University of Mashhad; ${ }^{3}$ Crop Physiology, Faculty of Agriculture, Ferdowsi University of Mashhad; \\ ${ }^{4}$ Department of Agronomy, Faculty of Agriculture, Ferdowsi University of Mashhad, Iran
}

\begin{abstract}
Salinity of irrigation water is an important limitation factor in crop production such as potato worldwide. Foliar application of anti-stress compounds containing mineral nutrients is one of the possible solutions for salinity mitigation. In this field experiment the effects of silicone compounds on potato (cv. Agria) performance was studied as a split plot based on randomised complete block design with three replications at Ferdowsi University of Mashhad, Iran, during 2016 cropping season. Treatments included irrigation salinity [0.3 (non-stress), 5, 8 and $12 \mathrm{dS} . \mathrm{m}^{-1}$ ] and foliar application of potassium sulphate $(1000 \mathrm{ppm})$, sodium silicate nanoparticles $(400 \mathrm{ppm})$ and silica $(1000 \mathrm{ppm})$. Results indicated that salinity decreased transpiration rate, stomatal conductance, quantum yield of PSII, membrane stability index, carotenoids, tuber number per plant and tuber yield while it improved water use efficiency and tuber dry matter percentage. Foliar application of anti-stress compounds positively affected quantum yield of PSII, carotenoids content, DPPH radical scavenging activity, tuber number per plant, tuber yield and tuber dry matter percentage. Although, application of all compounds improved most biochemical and photosynthetic traits, but ameliorative effect of the two silicon compounds, especially sodium silicate nanoparticles was more evident. It seems that silicon application could be an effective strategy in reducing salinity effects and its efficiency will be increased when is used as nanoparticles.
\end{abstract}

Correspondence: Jafar Nabati, Research Centre for Plant Sciences, Ferdowsi University of Mashhad, Iran.

E-mail: jafarnabati@ferdowsi.um.ac.ir

Key words: Foliar application; photosynthesis; quantum yield of PSII; sodium silicate.

Received for publication: 6 January 2018.

Revision received: 1 July 2018.

Accepted for publication: 19 July 2018.

(C) Copyright: the Author(s), 2019

Licensee PAGEPress, Italy

Italian Journal of Agronomy 2019; 14:1182

doi:10.4081/ija.2019.1182

This article is distributed under the terms of the Creative Commons Attribution Noncommercial License (by-nc 4.0) which permits any noncommercial use, distribution, and reproduction in any medium, provided the original author(s) and source are credited.

\section{Introduction}

Increasing demand for domestic and industrial water use, along with the reduction of groundwater level, has pushed the agricultural sector to reduce the use of freshwaters and to use low quality waters instead. Therefore, using saline water in the future for agricultural production is unavoidable (Hashemi et al., 2010; Yousef et al., 2015; Sattar et al., 2016).

Among agricultural crops, potato is of high paramount importance in human and livestock nutrition. The salinity of irrigation water in potato-cultivated lands of Iran has been increased in recent years, which resulted in the more use of saline and unconventional waters in cultivation of this crop. Therefore, adoption of agronomic management strategies and using techniques reducing salinity stress induced by irrigation water salts is essential in potato production (Kaya et al., 2001; Hussein et al., 2012). Among these, foliar application of compounds, which increases plant resistance to environmental stresses, is an appropriate strategy for yield improvement in the presence of environmental stresses (Kaya et al., 2001; Hussein et al., 2012).

Potassium (Kaya et al., 2001; Hussein et al., 2012; Yousef et al., 2015) and silicon (Epstein, 2009; Lobata et al., 2009; Haghighi and Pessarakli, 2013) are of elements with positive effects in saline conditions. It is accepted that synergistic role of potassium with other macro elements including nitrogen, phosphorus and calcium leads to more absorption of water and nutrients and finally yield improvement (Kaya et al., 2001; Shabala and Cuin, 2007; Yousef et al., 2015).

A study on potassium application in salinity conditions indicated more negative effects of salinity on photosynthesis of barley in potassium deficiency conditions (Degl'Innocenti, 2009). Also it is reported that potassium reduces water loss of plant tissues and increases water use efficiency (WUE) through its effects on stomatal closure and maintaining cell turgescence which all finally leads to lower effects of stress on plant (Imas and Magan, 2000).

Despite silicon has not been considered as an essential element in plant nutrition, but many useful effects of this element especially in stress conditions are reported (Al-Aghabary et al., 2004; Epstein, 2009; Haghighi and Pessarakli, 2013; Sattar et al., 2016).

Silicon improves plant ability for light harvesting by increasing chlorophyll concentration in leaf area unit and finally increases photosynthesis (Lobata et al., 2009; Shen et al., 2010; Silva et al., 2012;Haghighi and Pessarakli, 2013; Sattar et al., 2016). Silicon also plays an effective role in plant water balance through its sequestration in leaf cuticle layers inhibiting water loss and also increases physical resistance of leaf in stress conditions (Epstein, 2009; Lobata et al., 2009; Silva et al., 2012). There are reports on positive inductive role of silicon on plant defence system and decreasing the effect of stress through increasing free oxygen radical scavenging capacity (Al-Aghabary et al., 2004; Epstein, 2009; 
Hashemi et al., 2010; Shen et al., 2010; Sattar et al., 2016).

Nowadays, special attention has been paid to the use of nanotechnologies including nanoparticles in crop production (Ruffini and Cremonini, 2009; Haghighi and Pessarakli, 2013). Nanoparticles have unique criteria due to their small size and could change physico-chemical characteristics of elements compared to their common form. They also have a higher surface, which increases their solubility and surface reactivity (Haghighi and Pessarakli, 2013). Despite the widespread use of silicon compounds in different crop production systems, application of its nanoparticles has not been widely used (Ruffini and Cremonini, 2009).

Therefore, in this experiment effect of foliar application of common forms of silicon and potassium on photosynthesis, biochemical criteria and potato tuber yield was studied under irrigation with saline water. Also, the comparison of the effects of sodium silicate nanoparticles and common form of the silicon present in market was carried out to study the possibility of expanding application of these particles.

\section{Materials and methods}

This experiment was conducted as split-plot based on randomised complete block design with three replications in spring and summer of 2016 in research station of Faculty of Agriculture, Ferdowsi University of Mashhad. Treatments included irrigation salinity levels [0.3 (non-stress), 5, 8 and $12 \mathrm{dS} . \mathrm{m}^{-1}$ ] as main plots and three anti-stress compounds such as potassium sulphate $\left(\mathrm{K}_{2} \mathrm{SO}_{4}\right)(1000 \mathrm{ppm})$, sodium silicate nanoparticles (400 ppm) and silica $\left(\mathrm{SiO}_{2}\right)(1000 \mathrm{ppm})$ along with a control as sub-plots. Concentrations of potassium sulphate and sodium silicate nanoparticles were determined based on the primary studies (not published). Silica source, known as Silicon Power brand, was procured from Khosheh Parvaran Zistfanavar Company. Particle size of sodium silicate nanoparticles was $68 \mathrm{~nm}$ as shown in Figure 1.

Potato tubers (cv. Agria) used in this experiment were similar according to physiological age and had 3-5 green buds with 1-1.5 $\mathrm{cm}$ length. Each experimental plot with a total area of $15 \mathrm{~m}^{2}$ consisted of 4 rows of 5-meter length, spaced at $75 \mathrm{~cm}$ apart. Tubers were planted in May $16^{\text {th }}$ in $20 \mathrm{~cm}$ intervals within the rows. According to soil analysis (Table 1), no potassium and phosphorus fertilisers was needed to add to the soil (this amount of potassium and phosphate is enough to produce 40 ton of potatoes per hectare) while $200 \mathrm{~kg} \cdot \mathrm{ha}^{-1}$ nitrogen (46\% Urea) was applied in three times at planting, two and four weeks after planting.

Salinity treatment were imposed by dissolving $\mathrm{NaCl}$ in water source based on the ionisation coefficient after the tubers and seedlings were irrigated by normal water in the early growth stages and establishment till to 3-4 leaf stage in one month after planting. Foliar application of anti-stress compounds was carried out two weeks after imposing salinity stress and in two steps with 10 days intervals (40 days after planting) and 20 days after salinity stress (50 days after planting) using a hand sprayer at the end of the day. Biochemical and photosynthetic criteria was assessed one week after the second application of anti-stress compounds. Photosynthesis and chlorophyll fluorescence measurement were carried out in sunny conditions during 10:00-12:00 AM. Leaf chlorophyll fluorescence was measured by fluorimeter (OS1-FL model) and quantum yield of PSII was calculated using eq. 1 (Maxwell and Johnson, 2000).
$\Phi P S \Pi=\frac{F^{\prime} m-F_{0}^{\prime}}{F^{\prime} m}$

DPPH (1,1-diphenyl-2-picrylhydrazyl) radical scavenging activity was determined based on the method described by Abe et al. (1998). To achieve this, Ethanol solution of $10^{-4} \mathrm{M}$ DPPH was prepared freshly and refrigerated till needed. $100 \mathrm{mg}$ of fresh leaves homogenised in liquid nitrogen and $1 \mathrm{ml}$ of ethanol as solvent was added to sample. Aliquots $(50 \mu \mathrm{L})$ of extract were mixed with $950 \mu \mathrm{L}$ of DPPH solution and were quickly incubated at room temperature in darkness for $30 \mathrm{~min}$. Decrease in absorbance of DPPH solution was evaluated at $517 \mathrm{~nm}$. Ascorbic acid was used as a standard.

An infrared gas analyser model LCA4 (ADC Bio Scientific Limited England) was used to measure net photosynthesis, transpiration and stomatal conductance in the youngest fully expanded leaf of two plants in each plot (Olcer et al., 2001). Instantaneous water use efficiency was calculated by dividing photosynthesis to leaf transpiration (Haghighi and Pessarakli, 2013).

To determine cell membrane stability index (MSI), the youngest fully expanded leaf of one plant in each plot was separated and maintained in vials containing $100 \mathrm{ml}$ distilled water. $\mathrm{EC}_{1}$ was measured after $24 \mathrm{~h}$ using electrical conductivity meter (Jenway Model). $\mathrm{EC}_{2}$ was measured after the vials was autoclaved for an hour in $123^{\circ} \mathrm{C}$ and $0.15 \mathrm{~atm}$ and were cooled. Finally, MSI was calculated using eq. 2 (Sairam, 1994).

$$
M S I=\left[\left(1-\left(E C_{1} / E C_{2}\right)\right] \times 100\right.
$$

Chlorophyll a, b and carotenoids contents were measured based on the method described by Dere et al. (1998). To achieve this, photosynthetic pigments were extracted by ethanol $96 \%$ in $100 \mathrm{mg}$ fresh leaf and absorbance was read in 470, 648 and $664 \mathrm{~nm}$ by Jenway UV-visible spectrophotometer Model 6305. Equations

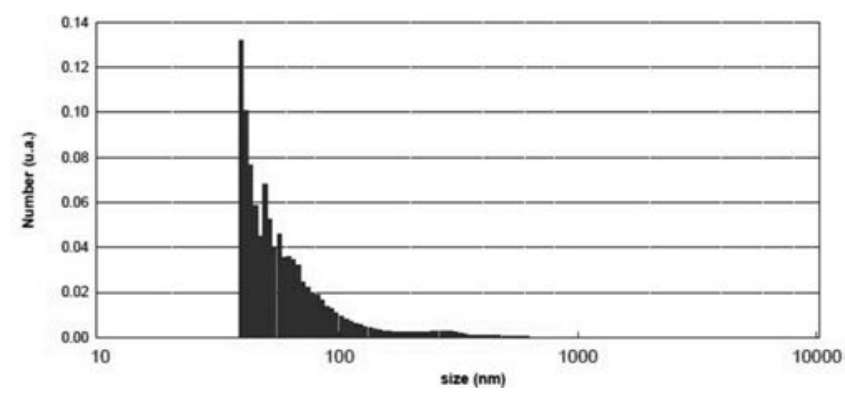

Figure 1. Sodium silicate nanoparticles diameter determined by particle size analyser system.

Table 1. Main physical and chemical properties of the soil at the study site.

\begin{tabular}{lccccc} 
Soil texture & $\begin{array}{c}\mathrm{K} \\
\left(\mathrm{mg} \mathrm{kg}^{-1}\right)\end{array}$ & $\begin{array}{c}\mathrm{P} \\
\left(\mathrm{mg} \mathrm{kg}^{-1}\right)\end{array}$ & $\begin{array}{c}\mathrm{N} \\
(\%)\end{array}$ & $\begin{array}{c}\mathrm{Na} \\
\left(\mathrm{mg} \mathrm{kg}^{-1}\right)\end{array}$ & $\mathrm{pH}$ \\
Silty Loam & 397 & 29.8 & 0.07 & 8.0 & 7.8 \\
\hline
\end{tabular}


3 to 5 were used to calculate concentration of Chlorophyll a, b and carotenoids. Total concentration of pigments was obtained from total chlorophyll and carotenoids concentration. The ratio of chlorophyll a and b was also calculated.

$\mathrm{Chl}_{\mathrm{a}}=13.36 \times \mathrm{A}_{664}-5.19 \times \mathrm{A}_{648}$

$\mathrm{Chl}_{\mathrm{b}}=27.43 \mathrm{~A}_{648}-8.12 \mathrm{~A}_{664}$

$\mathrm{C}(\mathrm{x}+\mathrm{c})=\left(1000 \times \mathrm{A}_{470}-2.13 \times \mathrm{Chl}_{\mathrm{a}}-97.64 \times \mathrm{Chl}_{\mathrm{b}}\right) / 209$

At the end of the growth season (late September), $2 \mathrm{~m}^{2}$ of each plot was harvested to determine tuber number per plant, tuber yield and dry matter percentage of tubers. To determine dry matter of tubers, samples were taken from each plot, weighed, cut and kept in oven for a week and finally weighed for its dry weight.

Analysis of variance and mean comparison was performed using SAS 9.1 and graphs were drawn by Excel software. Means were compared by Fisher's least significant difference test at a probability level of 0.05 .

\section{Results and discussion}

As is shown in Table 2, despite no significant changes in leaf photosynthesis between application of anti-stress compounds and control in non-stress condition, but the positive effects of antistress compounds application on leaf photosynthesis in 5 and 8 $\mathrm{dS} . \mathrm{m}^{-1}$ salinity treatments was revealed. In salinity level of 5 $\mathrm{dS} . \mathrm{m}^{-1}$, the highest photosynthesis rate was found in $\mathrm{K}_{2} \mathrm{SO}_{4}$ treatment showing $90 \%$ higher than photosynthesis compared with control. Although all anti-stress compounds positively affected leaf photosynthesis, the only significant difference compared to control was related to silicon application. Effect of anti-stress compounds was decreased as salinity level increased up to $12 \mathrm{dS} . \mathrm{m}^{-1}$ in a way that no difference was found among spraying treatments in this level of salinity (Table 2).

No significant difference was observed among spraying treatments according to leaf transpiration $(\mathrm{P} \geq 0.05)$ in non-stress conditions, but in salinity level of $5 \mathrm{dS} . \mathrm{m}^{-1}$, the highest difference with control (88\%) was found at leaves treated with $\mathrm{K}_{2} \mathrm{SO}_{4}$ and the lowest in silica treatment. Despite no difference was observed among spraying treatments in salinity levels of 8 and $12 \mathrm{dS} . \mathrm{m}^{-1}$, but the lowest leaf transpiration in all spraying treatments was found in 12 $\mathrm{dS} . \mathrm{m}^{-1}$ showing significant difference with other salinity levels (Table 2).

Interaction of salinity and anti-stress compounds on instantaneous water use efficiency of potato leaf was not significant but effect of salinity on this parameter was significant in a way that the highest instantaneous water use efficiency was found in salinity level of $12 \mathrm{dS} . \mathrm{m}^{-1}$ showing significant difference with lower salinity levels. The difference among other salinity levels was not significant (Figure 2A).

Foliar application of sodium silicate nanoparticles significantly decreased potato leaf stomatal conductance while application of the other compounds did not affect this parameter (Table 2). Salinity stress caused stomatal conductance to decrease and the most negative impact was found in control and salinity level of 8 $\mathrm{dS} . \mathrm{m}^{-1}$ which was lower than all the three spraying treatments in this salinity level (Table 2).

Similar to photosynthesis, quantum yield of PSII did not significantly differ between control and spraying treatments in nonstress conditions but a reduction of 37,24 and $45 \%$ was found in salinity levels of 5,8 and $12 \mathrm{dS} . \mathrm{m}^{-1}$, respectively compared to control and the lowest mean of this parameter in each salinity level was found in control while quantum yield of PSII in leaves treated with anti-stress compounds showed impressive stability in saline conditions and had no significant difference with non-stress conditions. Also, no significant difference was observed among three anti-stress compounds and salinity levels according to this parameter (Table 2).

Despite of the fact that DPPH radical scavenging activity was

Table 2. Interaction effect between irrigation salinity and foliar application of anti-stress compounds on net photosynthesis rate (Pn), Transpiration rate (Tr), Stomatal conductance (SC), Quantum yield of PSII (QY PSII) and DPPH radical scavenging (DPPH) in potato.

\begin{tabular}{|c|c|c|c|c|c|c|c|}
\hline $\begin{array}{l}\text { Irrigation salinity } \\
\left(\mathrm{dS} . \mathrm{m}^{-1}\right)\end{array}$ & $\begin{array}{l}\text { Anti-stress } \\
\text { compounds }\end{array}$ & $\begin{array}{c}\text { Pn } \\
\left(\mu m o l ~ C O^{2}\right. \\
\left.m^{-2} s^{-1}\right)\end{array}$ & $\begin{array}{c}\mathrm{Tr} \\
(\mathrm{mmol} \\
\left.\mathrm{m}^{-2} \mathrm{~s}^{-1}\right)\end{array}$ & $\begin{array}{c}\mathrm{SC} \\
(\mathrm{mmol} \\
\left.\mathrm{m}^{-2} \mathrm{~s}^{-1}\right)\end{array}$ & $\begin{array}{c}\mathrm{SC} \\
(\mathrm{mmol} \\
\left.\mathrm{m}^{-2} \mathrm{~s}^{-1}\right)\end{array}$ & QY PSII & $\begin{array}{c}\text { DPPH } \\
\text { (Ascorbate } \\
\mathrm{mg} \mathrm{g}^{-1} \mathrm{FW} \text { ) }\end{array}$ \\
\hline Non-saline (0.3) & $\begin{array}{c}\text { Control } \\
\text { Nano- } \mathrm{NaSiO}_{3} \\
\mathrm{~K}_{2} \mathrm{SO}_{4} \\
\mathrm{SiO}_{2}\end{array}$ & $\begin{array}{l}6.49 \\
5.13 \\
7.59 \\
6.10\end{array}$ & $\begin{array}{l}1.95 \\
1.77 \\
1.48 \\
1.82\end{array}$ & $\begin{array}{l}25.1 \\
17.8 \\
29.7 \\
24.4\end{array}$ & $\begin{array}{l}25.1 \\
17.8 \\
29.7 \\
24.4\end{array}$ & $\begin{array}{l}0.548 \\
0.530 \\
0.453 \\
0.565\end{array}$ & $\begin{array}{l}1.833 \\
2.805 \\
2.035 \\
1.921\end{array}$ \\
\hline 5 & $\begin{array}{c}\text { Control } \\
\text { Nano- } \mathrm{NaSiO}_{3} \\
\mathrm{~K}_{2} \mathrm{SO}_{4} \\
\mathrm{SiO}_{2}\end{array}$ & $\begin{array}{c}6.09 \\
4.86 \\
11.60 \\
6.14\end{array}$ & $\begin{array}{l}1.51 \\
1.71 \\
2.84 \\
1.39\end{array}$ & $\begin{array}{l}16.6 \\
19.2 \\
23.6 \\
20.2\end{array}$ & $\begin{array}{l}16.6 \\
19.2 \\
23.6 \\
20.2\end{array}$ & $\begin{array}{l}0.343 \\
0.491 \\
0.466 \\
0.471\end{array}$ & $\begin{array}{l}2.149 \\
1.716 \\
1.963 \\
2.824 \\
\end{array}$ \\
\hline 8 & 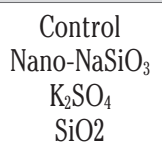 & $\begin{array}{l}6.28 \\
8.11 \\
8.14 \\
9.60\end{array}$ & $\begin{array}{l}1.66 \\
2.08 \\
1.57 \\
2.04\end{array}$ & $\begin{array}{c}8.5 \\
19.6 \\
20.3 \\
23.3\end{array}$ & $\begin{array}{c}8.5 \\
19.6 \\
20.3 \\
23.3\end{array}$ & $\begin{array}{l}0.410 \\
0.488 \\
0.542 \\
0.477\end{array}$ & $\begin{array}{l}1.043 \\
2.434 \\
2.261 \\
2.050\end{array}$ \\
\hline 12 & $\begin{array}{c}\text { Control } \\
\text { Nano- } \mathrm{NaSiO}_{3} \\
\mathrm{~K}_{2} \mathrm{SO}_{4} \\
\mathrm{SiO}_{2}\end{array}$ & $\begin{array}{l}5.13 \\
5.95 \\
4.11 \\
6.96\end{array}$ & $\begin{array}{l}0.95 \\
0.76 \\
0.65 \\
0.89\end{array}$ & $\begin{array}{l}16.6 \\
17.4 \\
17.4 \\
19.8\end{array}$ & $\begin{array}{l}16.6 \\
17.4 \\
17.4 \\
19.8\end{array}$ & $\begin{array}{l}0.299 \\
0.447 \\
0.547 \\
0.514\end{array}$ & $\begin{array}{l}2.190 \\
2.404 \\
2.222 \\
2.248\end{array}$ \\
\hline $\operatorname{LSD}_{(0.05)}$ & & 2.34 & 0.48 & 7.4 & 7.4 & 0.125 & 0.767 \\
\hline
\end{tabular}


not affected by silica and $\mathrm{K}_{2} \mathrm{SO}_{4}$ compounds in non-stress conditions, but an increase of $53 \%$ was observed in sodium silicate nanoparticles application compared to control. No significant difference was found between anti-stress compounds and control according to DPPH radical scavenging activity in salinity level of $5 \mathrm{dS} . \mathrm{m}^{-1}$, but the difference among the three compounds was significant in a way that DPPH radical scavenging activity of the silica treated leaves was higher than $\mathrm{K}_{2} \mathrm{SO}_{4}$ and sodium silicate nanoparticles (Table 2). The effective role of foliar application of anti-stress compounds on DPPH radical scavenging activity was quite evident in salinity level of $8 \mathrm{dS} . \mathrm{m}^{-1}$ and 2.3, 2.2 and 2 times increase was observed in sodium silicate nanoparticles, $\mathrm{K}_{2} \mathrm{SO}_{4}$ and silica, respectively compared to control. But, in salinity level of 12 $\mathrm{dS} . \mathrm{m}^{-1}$, despite the high DPPH radical scavenging activity of antistress compounds, no significant difference was observed between these treatments and control (Table 2).

Data on the photosynthesis parameters revealed that despite leaf area was severely affected by salinity, but photosynthesis per leaf area unit (data not shown) was not impressively declined.

Since increment of leaf thickness specially in parenchyma tissues is one of the strategies inhibiting the destruction of leaf photosynthesis structure (Gao et al., 2015), it seems that in the present study, increasing the density of cells containing photoreceptor pigments in leaf cross section has led to photosynthesis stability in leaf area unit in a large extent. Also, it has been mentioned that potassium contributes to enzyme proteins production (Hasegawa et al., 2000; Shabala and Cuin, 2007) through synergistic absorption of macro elements in stress conditions (Kaya et al., 2001; Shabala and Cuin, 2007). So it seems that partly positive influence of $\mathrm{K}_{2} \mathrm{SO}_{4}$ on leaf photosynthesis especially in $8 \mathrm{dS} \cdot \mathrm{m}^{-1}$, is due to the indirect effect of potassium through production of enzymes involved in photosynthesis. Although, presence of sulphur in this compound possibly has positive effect on plant criteria, but regarding the bold role of potassium as an anti-stress element, the positive effects of $\mathrm{K}_{2} \mathrm{SO}_{4}$ is greatly attributed to this element. Generally, in the present study, application of the two silicon compounds had little effects on net photosynthesis rate of potato. However, the results of the previous studies indicated the effective role of silicon on this parameter in several plants e.g. maize (Zea mays L.) (Sattar et al., 2016), tomato (Solanum lycopersicum) (Haghighi and Pessarakli, 2013; Silva et al., 2012) and pepper (Capsicum annum L.) (Lobata et al., 2009).

Potato leaf transpiration and stomatal conductance were decreased as salinity level increased independent of the anti-stress compounds used. Similar results have been reported on different plants in stress conditions (Silva et al., 2012; Haghighi and Pessarakli, 2013; Sattar et al., 2016). It is accepted that in saline conditions, leaf stomata are closed due to secondary drought stress caused by higher soil water potential, resulting in reduced leaf transpiration, stomatal conductance and finally plant water loss (Degl'Innocenti et al., 2009; Hashemi et al., 2010; Shen et al., 2010). As the results of the present study showed, transpiration was more affected than stomatal conductance by salinity stress in all salinity levels especially $12 \mathrm{dS} \cdot \mathrm{m}^{-1}$. Since stomata ability is of high paramount importance in gas exchange specially $\mathrm{CO}_{2}$ to supply photosynthesis precursor, so non-significant effect of salinity on photosynthesis could be partly attributed to maintenance of leaf stomatal conductance. Also, the increment of instantaneous WUE was not unexpected regarding little changes in photosynthesis and $50-60 \%$ reduction of leaf transpiration in anti-stress treated leaves in salinity level of $12 \mathrm{dS} \cdot \mathrm{m}^{-1}$ (Figure 2, Table 3). Researchers have stated that under stress conditions, changes such as increasing the thickness of the leaf parenchyma tissue and leaf cuticle layer along with leaf area reduction occur which increases WUE to improve biomass production, despite many of the yield attributed parameters are declined (Hasegawa et al., 2000).

Reduction of quantum yield of PSII with increasing salinity level compared to control, indicates the negative effect of salinity stress on photoreceptor centres (Hasegawa et al., 2000; AlAghabary et al., 2004). This reduction seems to be the result of the effect of secondary oxidative stress caused by salinity stress on electron transport chain and its protein centres (Hasegawa et al., 2000; Yousef et al., 2015) inhibiting energy received transfer from photoreceptor centres to electron transport chain and their destruction through a negative feedback, all resulted in quantum yield reduction of PSII. Unlike, this parameter remained stable in all
A
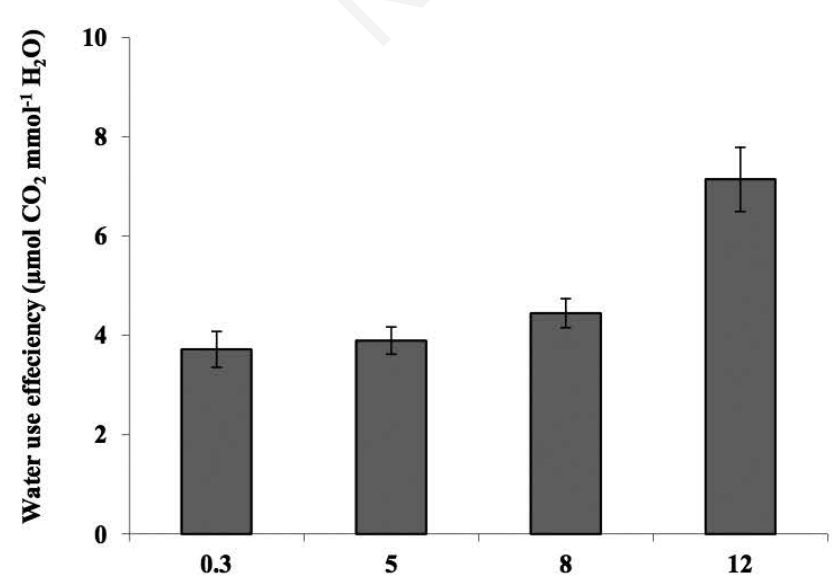

Irrigation salinity levels $\left(\mathrm{dS} \mathrm{m} \mathrm{m}^{-1}\right)$
B

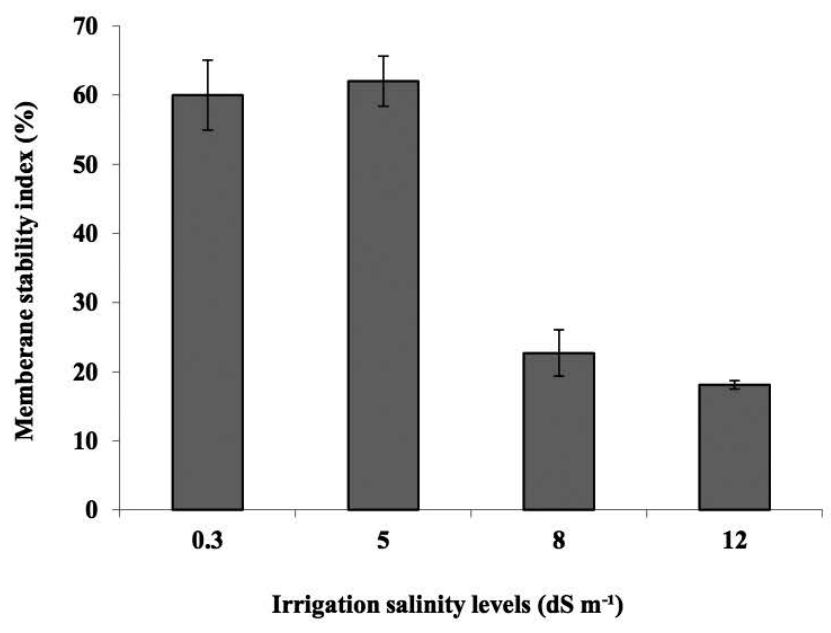

Figure 2. Effect of irrigation salinity on water use efficiency (A) and membrane stability index (B) of potato leaf. 
spraying treatments and salinity levels, improvement of quantum yield of PSII as a result of potassium and silicon application is shown in other studies (Al-Aghabary et al., 2004; Degl'Innocenti et al., 2009; Sattar et al., 2016). Also, increment of DPPH radical scavenging activity as an indicator of total antioxidant capacity in leaves treated with all three compounds of $\mathrm{K}_{2} \mathrm{SO}_{4}$, Sodium silicate nanoparticles and $\mathrm{SiO}_{2}$ specially in salinity levels of 8 and 12 $\mathrm{dS} . \mathrm{m}^{-1}$, indicates that improvement in plant defence system as a result of anti-stress compounds application has led to an increased capacity to remove free oxygen radicals and reduced salinityinduced oxidative stress in a way that photoreceptor centres and quantum yield of PSII had not been affected by salinity.

Despite cell membrane stability of potato leaves was not affected by anti-stress compounds application, salinity and their interaction (data not shown). But, this parameter was significantly decreased as salinity level increased, reaching to the lowest level in salinity levels of 8 and $12 \mathrm{dS} . \mathrm{m}^{-1}$ (Figure 2B). Reduction of cell membrane stability in stress conditions has been attributed to an increase in lipid peroxidation of cell membrane (Hasegawa et al., 2000; Kaya and Higgs, 2001; Shabala and Cuin, 2007; Gao et al., 2015).

In non-stress conditions when $\mathrm{K}_{2} \mathrm{SO}_{4}$ and sodium silicate nanoparticles were applied, chlorophyll $\mathrm{a}$ and $\mathrm{b}$ content in potato leaves was significantly increased compared to control in a way that an increase of 50 and $52 \%$ was found in total pigments concentration under two mentioned anti-stress treatments while no significant effect was found on leaf carotenoids content in nonstress conditions (Table 3). Also, no significant difference was found among spraying treatments in non-stress conditions according to chlorophyll a to $\mathrm{b}$ ratio due to the similar changes of chlorophyll a and b. In salinity level of $5 \mathrm{dS} \cdot \mathrm{m}^{-1}$, chlorophyll a, b, carotenoids content and total pigments concentration was higher than non-stress conditions while lower means of these parameters was found when anti-stress compounds were applied.

No significant difference was observed among anti-stress compounds and control according to $\mathrm{Chl} \mathrm{a} / \mathrm{b}$ (Table 3 ). In salinity level of $8 \mathrm{dS} . \mathrm{m}^{-1}$, only the effect of sodium silicate nanoparticles was significant on carotenoids content and $\mathrm{Chl} a / b$ and in salinity level of $12 \mathrm{dS} . \mathrm{m}^{-1}$, only carotenoids content of $\mathrm{SiO}_{2}$ treated leaves was significantly higher than the other anti-stress compounds treatments which led to the significant increase in total pigments concentration (TPC) of this treatment compared to control (Table 3).

The increase in $\mathrm{Chl} \mathrm{a} / \mathrm{b}$ and TPC of control under saline conditions is in consistence with data on photosynthesis stability (Tables 2 and 3 ) and approved the more concentrated parenchyma chlorophyll containing cells in leaf area unit which confirmed the previous study by Gao et al. (2015) on potato plantlets in saline environment.

In this study, two silicon containing treatment had significant and positive effects on traits related to photosynthesis pigments which showed the results of the others researchers (Al-Aghabary et al., 2004; Lobata et al., 2009; Silva et al., 2012; Haghighi and Pessarakli, 2013) while $\mathrm{K}_{2} \mathrm{SO}_{4}$ was not considered as an appropriate treatment. The effect of sodium silicate nanoparticles on TPC was significant in non-saline conditions and salinity level of 8 dS.m ${ }^{-1}$ while the positive effect of $\mathrm{SiO}_{2}$ was found in the highest salinity level $\left(12 \mathrm{dS} \cdot \mathrm{m}^{-1}\right)$. The more effectiveness of nanoparticles compared to the common form has been attributed to their unique features, reactivity and transfers in plant tissues (Haghighi and Pessarakli, 2013; Ruffini and Cremonini, 2009). Reduction of TPC in leaves treated by nanoparticles compared to $\mathrm{SiO}_{2}$ in $12 \mathrm{dS} . \mathrm{m}^{-1}$ may be possibly due to the presence of $\mathrm{Na}$ which had increased the pressure on leaves in high saline conditions. On the other hand, it may be possible that nanoparticles act as the secondary stress inducers due to their higher biological activity and permeability in plant tissues which along with vulnerability and lack of biochemical coherence and desirable cell structure, leads to defective in potato function in higher salinity levels.

Potato tuber number per plant was affected by irrigation water salinity and anti-stress compounds in a way that this parameter was decreased in anti-stress treatments compared to control and the lowest tuber number was found in application of sodium silicate nanoparticles (Figure 3). But, the positive effect of silicon containing compounds was revealed in saline conditions so that in salinity level of $5 \mathrm{dS} . \mathrm{m}^{-1}$, the highest number of tubers was observed in these treatments. Despite the positive effects of anti-stress compounds were severely decreased as salinity level increased, but application of sodium silicate nanoparticles resulted in higher tuber

Table 3. Interaction effects between irrigation salinity and foliar application of anti-steress compounds on concentration of Chlorophyll $a(\mathrm{Chl}$ a), Chlorophyll $b(\mathrm{Chl} b)$, Carotenoids (Cart), Total pigments (TPC) and Chlorophyll $a / b$ ratio $(\mathrm{Chl}$ a/b) at potato.

\begin{tabular}{|c|c|c|c|c|c|c|}
\hline $\begin{array}{l}\text { Irrigation salinity } \\
\left(\mathrm{dS} . \mathrm{m}^{-1}\right)\end{array}$ & $\begin{array}{l}\text { Anti-Stress } \\
\text { compounds }\end{array}$ & $\begin{array}{c}\text { Chl } a \\
\left(\mathrm{mg} \mathrm{g}^{-1} \mathrm{FW}\right)\end{array}$ & $\begin{array}{c}\mathrm{Chl} b \\
\left(\mathrm{mg} \mathrm{g}^{-1} \mathrm{FW}\right)\end{array}$ & $\begin{array}{c}\text { Cart } \\
\left(\mathrm{mg} \mathrm{g}^{-1} \mathrm{FW}\right)\end{array}$ & $\begin{array}{c}\text { TPC } \\
\left(\mathrm{mg} \mathrm{g}^{-1} \mathrm{FW}\right)\end{array}$ & $\mathrm{Chl} a / b$ \\
\hline Non-saline (0.3) & $\begin{array}{c}\text { Control } \\
\text { Nano-NaSiO } \\
\mathrm{K}_{2} \mathrm{SO}_{4} \\
\mathrm{SiO}_{2}\end{array}$ & $\begin{array}{l}0.835 \\
1.301 \\
1.320 \\
0.912\end{array}$ & $\begin{array}{l}0.447 \\
0.658 \\
0.721 \\
0.492\end{array}$ & $\begin{array}{l}0.157 \\
0.199 \\
0.144 \\
0.144\end{array}$ & $\begin{array}{l}1.440 \\
2.157 \\
2.185 \\
1.548\end{array}$ & $\begin{array}{l}1.86 \\
1.98 \\
1.81 \\
1.85\end{array}$ \\
\hline 5 & $\begin{array}{c}\text { Control } \\
\text { Nano- } \mathrm{NaSiO}_{3} \\
\mathrm{~K}_{2} \mathrm{SO}_{4} \\
\mathrm{SiO}_{2}\end{array}$ & $\begin{array}{l}1.015 \\
0.957 \\
0.668 \\
0.535\end{array}$ & $\begin{array}{l}0.530 \\
0.492 \\
0.412 \\
0.335\end{array}$ & $\begin{array}{l}0.171 \\
0.157 \\
0.098 \\
0.089\end{array}$ & $\begin{array}{l}1.716 \\
1.606 \\
1.178 \\
0.960 \\
\end{array}$ & $\begin{array}{l}1.90 \\
1.97 \\
1.64 \\
1.60 \\
\end{array}$ \\
\hline 8 & $\begin{array}{c}\text { Control } \\
\text { Nano-NaSiO } \\
\mathrm{K}_{2} \mathrm{SO}_{4} \\
\mathrm{SiO}_{2}\end{array}$ & $\begin{array}{l}1.125 \\
1.453 \\
1.131 \\
1.057\end{array}$ & $\begin{array}{l}0.595 \\
0.645 \\
0.610 \\
0.544\end{array}$ & $\begin{array}{l}0.193 \\
0.274 \\
0.204 \\
0.199\end{array}$ & $\begin{array}{l}1.913 \\
2.373 \\
1.945 \\
1.799\end{array}$ & $\begin{array}{l}1.88 \\
2.25 \\
1.85 \\
1.94\end{array}$ \\
\hline 12 & $\begin{array}{c}\text { Control } \\
\text { Nano- } \mathrm{NaSiO}_{3} \\
\mathrm{~K}_{2} \mathrm{SO}_{4} \\
\mathrm{SiO}_{2}\end{array}$ & $\begin{array}{l}1.063 \\
0.807 \\
1.196 \\
1.385\end{array}$ & $\begin{array}{l}0.564 \\
0.466 \\
0.604 \\
0.720\end{array}$ & $\begin{array}{l}0.169 \\
0.102 \\
0.203 \\
0.239\end{array}$ & $\begin{array}{l}1.796 \\
1.376 \\
2.003 \\
2.343\end{array}$ & $\begin{array}{l}1.93 \\
1.73 \\
1.98 \\
1.92\end{array}$ \\
\hline \multicolumn{2}{|c|}{$\operatorname{LSD}_{(0.05)}$} & 0.381 & 0.175 & 0.056 & 0.587 & 0.31 \\
\hline
\end{tabular}


number per plant (Figure 3). Unlike the reduction of tuber number in anti-stress treatments in non-stress conditions, tuber yield not only did not decrease, but also increased in application of sodium silicate nanoparticles and $\mathrm{SiO}_{2}$ compared to control (Figures 3 and 4). So, it could be concluded that in non-stress conditions, tuber weight was positively affected by silicon containing compounds in such a way that tuber yield increased despite, tuber number decreased. Different results were found in saline conditions and more severe reduction of tuber yield compared to tuber number was found in all salinity levels (Figures 3 and 4), which was due to the lower tuber weights. Moreover, in salinity level of $5 \mathrm{dS} . \mathrm{m}^{-1}$, tuber yield was significantly affected by both sodium silicate nanoparticles and $\mathrm{SiO}_{2}$ while in higher salinity levels, the only positive effect was found in sodium silicate nanoparticles (Figure 4).

Since in this study, salinity levels were higher than potato salinity tolerance threshold, reduction of yield and yield components was not unexpected. Yield reduction of different crop species in stress conditions also has been indicated in studies by Sattar et al. (2016) and Yousef et al. (2015). Similar to photosynthetic pigments and quantum yield of PSII, the more positive effects of sodium silicate nanoparticles was found on tuber number and yield compared to the other compounds. So, it seems that positive effects

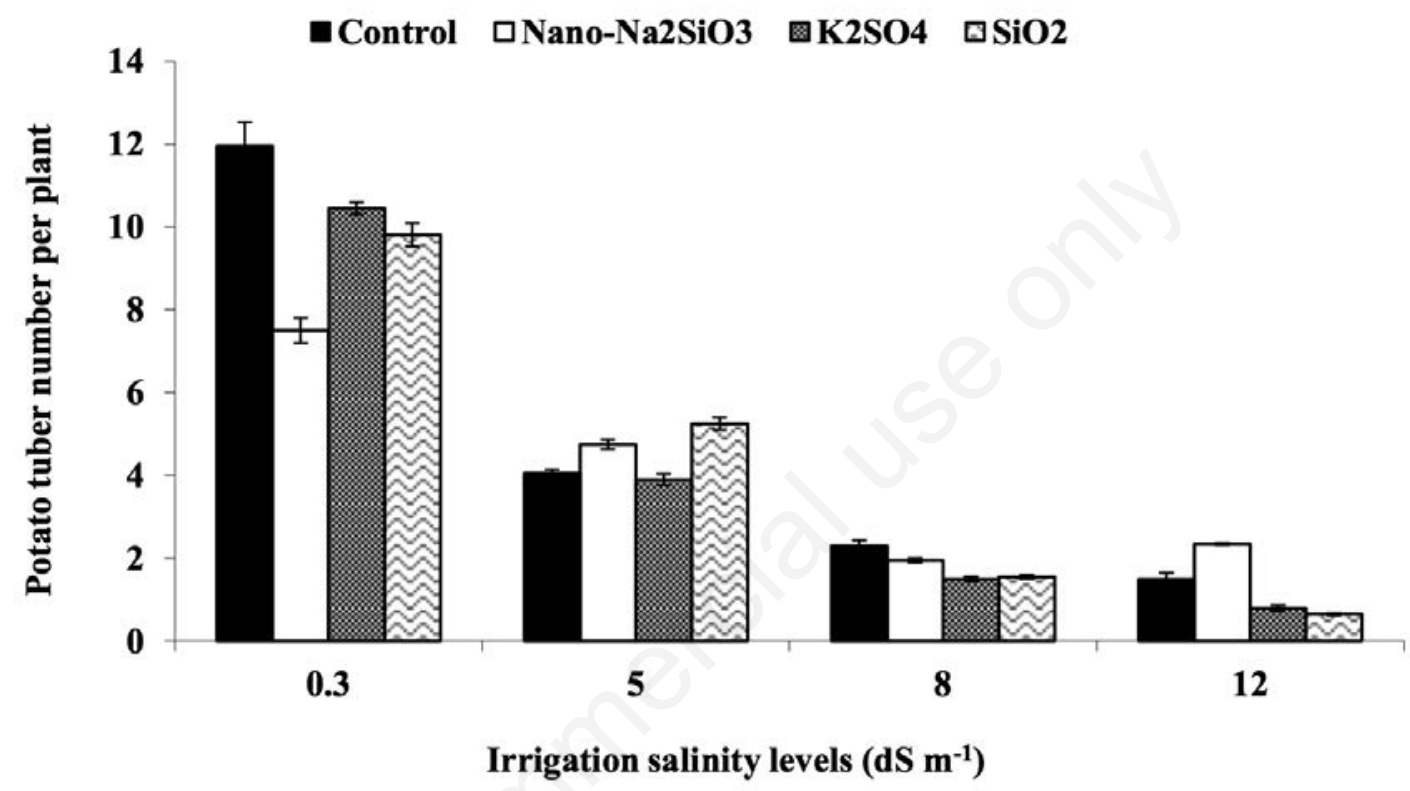

Figure 3. Effects of irrigation salinity and anti-stress compounds on potato tuber number per plant.

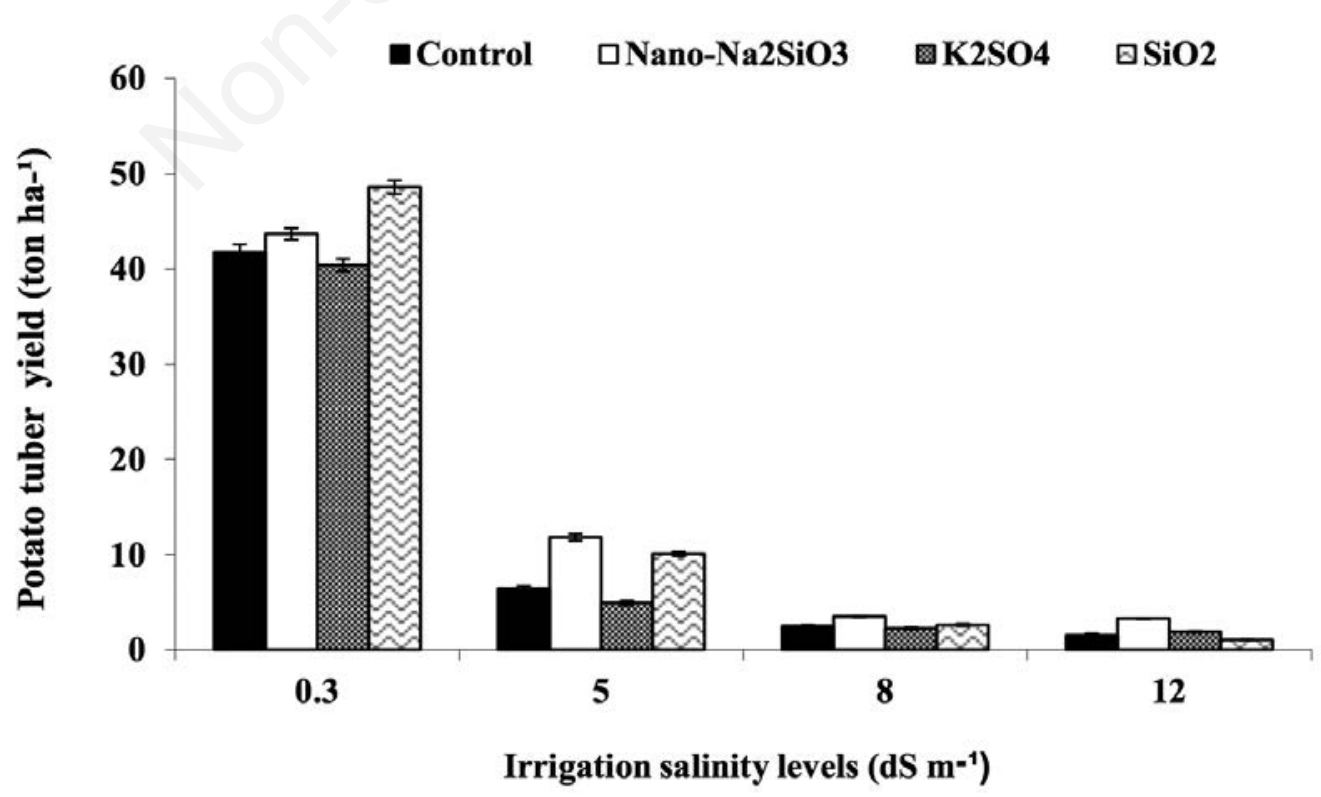

Figure 4. Effects of irrigation salinity and anti-stress compounds on potato tuber yield. 


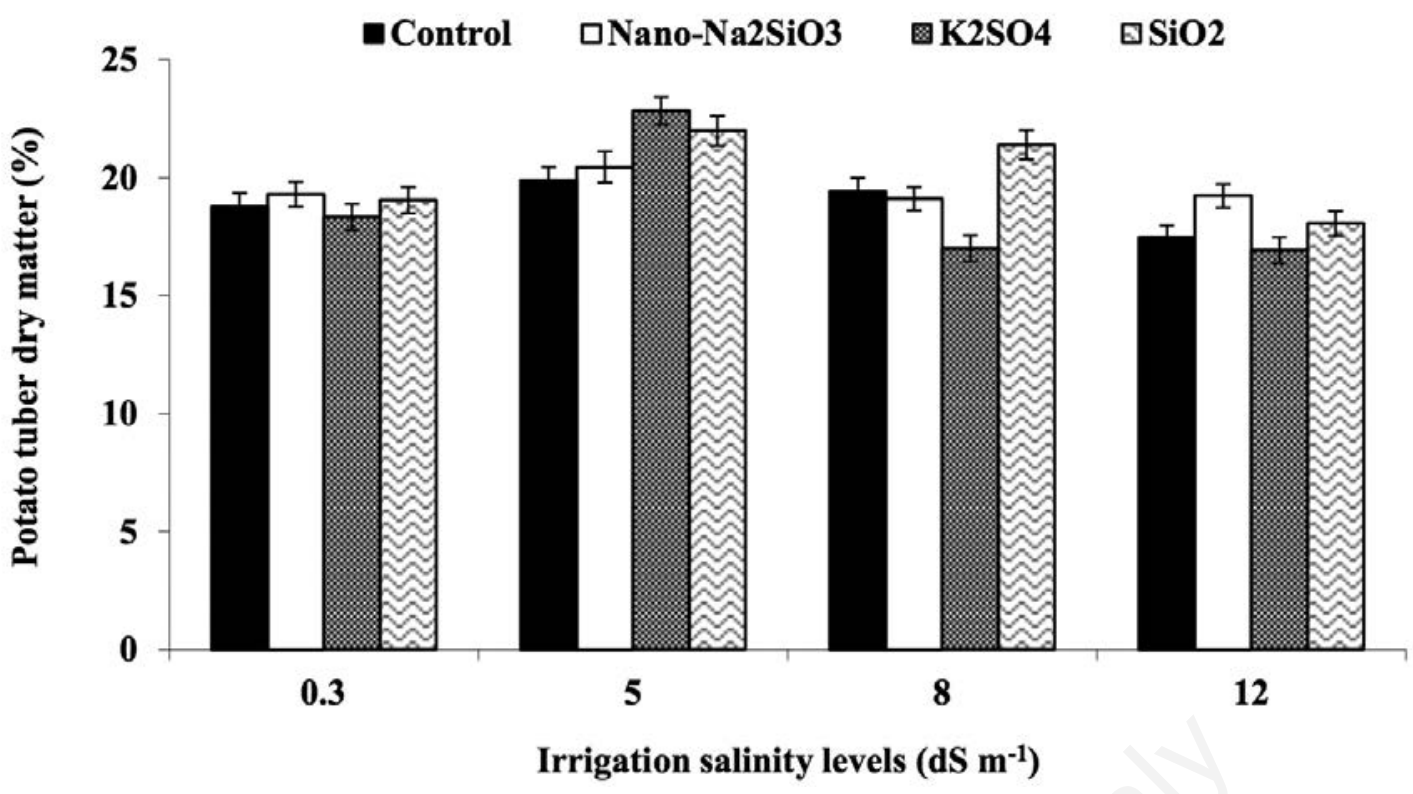

Figure 5. Effects of irrigation salinity and anti-stress compounds on potato tuber dry matter.

of sodium silicate nanoparticles during growth season coincided with the determination period of number and size of sink, has finally increased potato yield.

Despite application of potassium for tuber yield improvement in stress conditions has been suggested in previous studies, but in the present study, foliar application of $\mathrm{K}_{2} \mathrm{SO}_{4}$ did not affected potato yield neither in non-stress nor in stress conditions, it seems that due to the high amount of potassium in field soil (Table 1).

Little effects of salinity and anti-stress compounds was found on potato tuber dry matter in a way that only $2 \%$ increase of this parameter was observed in application of sodium silicate nanoparticles and $\mathrm{SiO}_{2}$ in non-stress conditions. Also, under stress conditions, application of the two mentioned compounds increased tuber dry matter in most levels of salinity stress while potassium application increased dry matter only in salinity level of $5 \mathrm{dS} . \mathrm{m}^{-1}$ (Figure 5). In all spraying treatments, tuber dry matter increased as salinity level increased to $8 \mathrm{dS} \cdot \mathrm{m}^{-1}$, but in the highest salinity level, tuber dry matter decreased in all spraying treatments except sodium silicate nanoparticles.

It seems that increasing salinity followed by greater (more intense) soil matric potential induced by irrigation water salts, has decreased water content of tubers which may be due to the inability of the roots adjacent to the tubers in water supply for tubers or direct effects of saline soil in contact with the tubers. Also, increase in thickness of the tubers skin as a protective strategy in stress conditions (Konstankiewicz and Zdunek, 2001) may be another effective factor in increment of skin thickness of tubers as well as tuber dry matter.

\section{Conclusions}

Generally, results of the present study indicated that salinity stress did not have impressive effects on photosynthesis per leaf area unit and even TPC was increased in leaf weight unit in stress conditions. But, transpiration, stomatal conductance, quantum yield of PSII, cell membrane stability index, carotenoids content, tuber number per plant and tuber yield were reduced under saline conditions while instantaneous WUE and tuber dry matter percentage were increased. Foliar application of anti-stress compounds lowered the effects of salinity on quantum yields of PSII, carotenoids content, DPPH radical scavenging activity, tuber number per plant, tuber yield and tuber dry matter percentage. All three anti-stress compounds used in this experiment positively affected biochemical and photosynthetic criteria, but effect of silicon containing compounds specially sodium silicate nanoparticles was more relevant in terms of yield attributed criteria. Also, $\mathrm{K}_{2} \mathrm{SO}_{4}$ had the lowest effect on the studied criteria with no significant effect on tuber yield. According to the results of this experiment, it could be concluded that silicon application may be an effective strategy in reducing salinity effects in saline conditions and more efficiency will be achieved by using this element as nanoparticles.

\section{References}

Abe N, Murata T, Hirota A, 1998. Novel 1,1-diphenyl-2-picryhydrazyl- radical scavengers, bisorbicillin and demethyltrichodimerol, from a fungus. Biosci. Biotech. Biochem. 62:661-2.

Al-Aghabary K, Zhu Z, Shi QH, 2004. Influence of silicon supply on chlorophyll content, chlorophyll fluorescence, and antioxidative enzyme activities in tomato plants under salt stress. J. Plant. Nutr. 27:2101-15.

Degl'Innocenti E, Hafsi C, Guidi L. Navari-Izzo F, 2009. The effect of salinity on photosynthetic activity in potassium-deficient barley species. Plant Physiol. 166:1968-81.

Dere S, Gines T, Sivaci R, 1998. Spectrophotometric determination of chlorophyll - $\mathrm{a}, \mathrm{b}$ and total carotenoid contents of some algae species using different solvents. Turk. J. Bot. 22:13-7.

Epstein E, 2009. Silicon: its manifold roles in plants. Ann. Appl. Biol. 155:155-60.

Gao H, Yang H, Bai J, Liang X, Lou Y, Zhang J, Wang D, Zhang 
J, Niu S, Chen Y, 2015. Ultrastructural and physiological responses of potato (Solanum tuberosum L.) plantlets to gradient saline stress. Front. Plant Sci. 5:1-14.

Haghighi M, Pessarakli M, 2013. Influence of silicon and nano-silicon on salinity tolerance of cherry tomatoes (Solanum lycopersicum L.) at early growth stage. Sci. Hort. 161:111-7.

Hasegawa PM, Bressan A, Zhu JK, Bohnert J, 2000. Plant cellular and molecular responses to high salinity. Annu. Rev. Plant Physiol. Plant Mol. Biol. 51:463-99.

Hashemi A, Abdolzadeh A Sadeghipour HR, 2010. Beneficial effects of silicon nutrition in alleviating salinity stress in hydroponically grown canola, Brassica napus L., plants. Soil Sci. Plant Nutr. 56:244-53.

Hussein MM, El-Faham SY, Alva AK, 2012. Pepper plants growth, yield, photosynthetic pigments, and total phenols as affected by foliar application of potassium under different salinity irrigation water. Agr. Sci. 3:241-8.

Kaya C, Kirnak H, Higgs D, 2001. Enhancement of growth and normal growth parameters by foliar application of potassium and phosphorus in tomato cultivars grown at high $(\mathrm{NaCl})$ salinity. J. Plant. Nutr. 24:357-67.

Konstankiewicz K, Zdunek A, 2001. Influence of turgor and sell size on the creaking of potato tissue. Int. Agrophys. 15:27-30.

Lobata AKS, Coimbra GK, Neto MAM, Costa RCL, Santos Filho BG, Oliveira Neto CF, Luz LM, Barreto AGT, Pereira BWF, Alves GAR, Monteiro BS, Marochio CA, 2009. Protective action of silicon on water relations and photosynthetic pigments in pepper plants induced to water deficient. Res. J. Biol. Sci. 4:617-23.

Maser P, Gierth M, Schroeder IJ, 2002. Molecular mechanisms of potassium and sodium uptake in plant. Plant Soil. 247:43-54.

Maxwell K, Johnson GN, 2000. Chlorophyll fluorescence - a prac- tical guide. J. Exp. Bot. 51:659-68.

Ruffini CM, Cremonini R, 2009. Nanoparticles and higher plants. Caryologia. 62:161-5.

Sairam R.K. 1994. Effect of moisture stress on physiological activities of two contrasting wheat genotypes. Ind. J. Exp. Biol. 32:594-7.

Sattar A, Cheema MA, Ali H, Sher A, Ijaz M, Hussain M, Hassan W, Abbas T, 2016. Silicon mediates the changes in water relations, photosynthetic pigments, enzymatic antioxidants activity and nutrient uptake in maize seedling under salt stress. Grassl. Sci. 62:262-9.

Shabala S, Cuin TA, 2007. Potassium transport and plant salt tolerance. Physiol. Plant. 133:651-69.

Shen X, Zhou Y, Duan L, Li Z, Eneji AE, Li J, 2010. Silicon effects on photosynthesis and antioxidant parameters of soybean seedlings under drought and ultraviolet-B radiation. Plant Physiol. 167:1248-52.

Silva ON, Lobato AKS, Ávila FW, Costa RCL, Oliveira Neto CF, Santos Filho BG, Martins Filho AP, Lemos RP, Pinho JM, Medeiros MBCL, Cardoso MS, Andrade IP, 2012. Siliconinduced increase in chlorophyll is modulated by the leaf water potential in two water-deficient tomato cultivars. Plant Soil Envir. 58:481-6.

Yousef PY, Ahmad A, Hemant A, Ganie AH, Aref IM, Iqbal M, 2015. Potassium and calcium application ameliorates growth and oxidative homeostasis in salt-stressed Indian mustard (Brassica Juncea) plants. Pak. J. Bot. 47:1629-39.

Olcer H, Lloyd JC, Raines CA, 2001. Photosynthetic capacity is differentially affected by reductions in sedoheptulose-1, 7-bisphosphatase activity during leaf development in transgenic tobacco plants. Plant Physiol. 125:982-9. 